\title{
Local Use of Apisan Gel, A New Oral Care Product in the Treatment of Experimental Periodontitis Against the Background of Hyperacid Gastritis and Intoxication with Tobacco Smoke
}

\author{
Hiperasit Gastrit ve Tütün ile Zehirlenmeye Karşı Deneysel Periodontitis \\ Tedavisinde Yeni Bir Ağız Bakım Ürünü, Apisan Jelinin Lokal Kullanımı
}

\author{
(D) Lyudmila KRAVCHENKO1*, (D) Irina BORISYUK22, (D) Natali FIZOR22, (D) Liana UNHURIAN2, (D) Elena ZOLOTUKHINA1', (D) Olga GONCHARENKO1 \\ 1Odessa National Medical University, Faculty of Dentistry, Department of Therapeutic Dentistry, Odessa, Ukraine \\ 2Odessa National Medical University, Faculty of Pharmacy, Department of Organization and Economics of Pharmacy, Odessa, Ukraine
}

\begin{abstract}
Objectives: The aim of the work was to substantiate the use of a newly created oral care product in the treatment of periodontal disease reconstructed against the background of hyperacidic gastritis under the conditions of tobacco smoke intoxication.

Materials and Methods: The study was conducted in 2 stages. In the first stage, all experimental animals were divided into 4 groups: 1 ) intact, 2) with simulated periodontitis, 3) with reproduced periodontitis against the background of reproduced hyperacidic gastritis, 4) with reproduced periodontitis against the background of hyperacid gastritis under the conditions of tobacco smoking. Biochemical studies of gum homogenate with periodontitis in rats were conducted to determine the impact of stomach pathology and tobacco smoke as endogenous and exogenous risk factors. In stage 2, the effectiveness of local therapy with the use of the newly created oral care product and a comparator was studied in rats with reproduced periodontitis against the background of hyperacidic gastritis under the conditions of smoking.

Results: In the experimental periodontitis against the background of hyperacidic gastritis under the conditions of tobacco smoking, there were significant changes in the periodontal tissues characteristic of the inflammatory process: the activity of peroxide oxidation of lipid (POL) increased, activity of the antioxidant system decreased, and inflammatory markers increased when nonspecific protection was reduced. Local therapy in the rats using the new "Apisan" gel resulted in the correction of certain metabolic disorders, faster elimination of the harmful effects of the damaging factors, and restoration of the condition of periodontal tissues compared with the use of the comparator, the Asepta gel.

Conclusion: The therapeutic effectiveness of the new Apisan gel is due to the normalizing effect on the processes of POL, and inflammation and activation of the oral cavity protective systems during inflammatory periodontal disease occurring against the background of a concomitant stomach pathology, hyperacidic gastritis.
\end{abstract}

Key words: Apigel, periodontitis, hyperacidic gastritis, tobacco smoking, inflammation

ÖZ

Amaç: Çalışmanın amacı, tütün dumanı intoksikasyonu koşullarında hiperasidik gastritin zemininde oluşan periodontal hastalığın tedavisinde yeni oluşturulan ağız bakım ürününün kullanımını gerçekleștirmektir.

Gereç ve Yöntemler: Çalışma 2 aşamada gerçekleştirilmiştir. Illk aşamada, tüm deney hayvanları 4 gruba ayrılmıştır: 1) bozulmamış, 2) simüle edilmiş periodontitis ile, 3) çoğaltılmış hiperasidik gastritin zemininde oluşturulan periodontitis ile, 4) tütün içme koşulları. Endojen ve eksojen risk faktörleri olarak mide patolojisi ve tütün dumanının etkisini belirlemek için periodontitisli sıçanlarda sakız homojenatının biyokimyasal çalışmaları yapıımıştır. ikinci aşamada, sigara içme koşulları altında hiperasidik gastrit zemininde oluşturulan periodontitisli sıçanlarda yeni oluşturulan ağız bakım ürünü ve karşılaştırıcı kullanımı ile lokal tedavinin etkinliği incelenmiştir.

Bulgular: Tütün içme koşulları altında hiperasidik gastrit zeminine karşı oluşan deneysel periodontitiste, enflamatuvar sürecin karakteristiği olan periodontal dokularda önemli değişiklikler vardı: lipit peroksit oksidasyonu (POL) aktivitesi artmış ve antioksidan sistemin aktivitesi azalmış spesifik

*Correspondence: E-mail: lianau@ukr.net, Phone: +38 (048) 723-35-67 ORCID-ID: orcid.org/0000-0001-5391-9676

Received: 10.10.2018, Accepted: 15.11.2018

๑Turk J Pharm Sci, Published by Galenos Publishing House. 
olmayan koruma azaltıldığında enflamatuvar belirteçler artmıştır. Sıçanlarda yeni “Apisan” jeli kullanılarak lokal terapi, belirli metabolik bozuklukların düzeltilmesi, zarar verici faktörlerin zararlı etkilerinin daha hızı ortadan kaldırılması ve karşılaștırıcının Asepta jelinin kullanımından daha çok periodontal dokuların durumunun yenilenmesi ile sonuçlanmıştır.

Sonuç: Yeni Apisan jelinin terapötik etkinliği, POL süreçleri, mide patolojilerinin zemininde hiperasidik gastrite eşlik eden enflamatuvar periodontal hastalık sürecinde oral kavite koruyucu sistemlerin iltihaplanması ve aktivasyonu üzerindeki normalleștirici etkiden kaynaklanmaktadır.

Anahtar kelimeler: Apigel, periodontitis, hiperasidik gastrit, tütün içme, enflamasyon

\section{INTRODUCTION}

Changes in the tissues of the oral cavity with manifestations of inflammation are often associated with diseases of the gastrointestinal tract (GIT), due to the morphofunctional unity of the digestive apparatus. There are ulcerative lesions, erosion, and aphthae of the oral cavity mucosa (OCM) in the pathology of the GIT due to trophic disorders. The presence of harmful habits, especially smoking, in patients with concomitant diseases of the GIT further enhances the severity of the inflammatory symptoms in the oral cavity. Dental deposit of smokers is a major provocative factor in the development of gum diseases and caries. ${ }^{1.2}$

In inflammatory diseases of the oral cavity, gastritis, among the concomitant GIT pathologies, makes up more than $70 \%$ of cases, the form and duration of which affect the functional state of the OCM. Changes in the oral cavity during chronic gastritis depend on the secretion and acid forming function of the stomach. Increased acidity in the stomach is accompanied by hypersalivation, pallor, edema and gingival inflammation, bleeding, decreased capillary stability, and reactivity of the OCM. ${ }^{3}$ By weakening the immune defense of the body, the concomitant GIT diseases create conditions for the affecting influence on the OCM and periodontium by the microflora present in the oral cavity and the endogenous periodontal pathogenic factors. In addition, current data suggest a negative impact of Helicobacter pylori infection ${ }^{4}$ and tobacco smoking ${ }^{5}$ on the incidence of OCM and periodontium diseases.

The mechanisms underlying the influence of changes in the GIT on the pathobiochemical reactions of the inflammatory process in the periodontal tissues and OCM and the possibility of treating such a combined pathology, taking into account the harmful habit of tobacco smoking, require a specific study. Therefore, we consider it relevant and promising for dentistry to search for and study the effectiveness of new means of local therapy of the OCM and periodontal diseases as a concomitant pathology of hyperacidic gastritis under the conditions of tobacco smoking.

The aim of the present work was to substantiate the local application of a newly created oral care product in the treatment of periodontal disease reconstructed against the background of hyperacidic gastritis under the condition of intoxication with tobacco smoke.

\section{MATERIALS AND METHODS}

The study was conducted on 72 male wistar rats, 1-1.5 months of age, weighing 180-220 g, which were in the vivarium of Odessa National Medical University on a standard feed for laboratory rats. According to the tasks of the experiment, the study was conducted in 2 stages. In the first stage the rats were divided into 4 groups (10 animals in each). The first group consisted of intact rats (control). In the second group of rats periodontitis was modeled. The third group consisted of rats in which, after reproduction of hyperacidic gastritis, periodontitis was modeled. The fourth group included rats in which, against the background of reproduced hyperacidic gastritis, periodontitis was modeled under the condition of tobacco smoke dosing. After conducting the first series of the experiment to determine the effect of concomitant stomach and tobacco smoke on metabolic disorders in the tissues of the oral cavity of rats upon reproduction of periodontitis, the effectiveness of local treatment with the use of the newly created drug was studied on the basis of apiproducts and other biologically active substances with anti-inflammatory, antimicrobial, and antioxidant effects ${ }^{6}$ and a comparator preparation, aseptic gel. The experimental animals were also divided into 4 groups: 1 ) intact (control); 2) rats with a reproduced model of periodontitis against the background of hyperacidic gastritis under the conditions of exposure to tobacco smoke; 3) the main one, which included newly treated rats with periodontal disease reproduced against the background of hyperacidic gastritis under the conditions of intoxication with tobacco smoke; 4) a comparison group, which included rats with a periodontitis model in groups 2 and 3 receiving local treatment with Asepta gel.

The gastroduodenal zone in the rats was affected by the addition of ammonium acetate $2 \mathrm{~g} / \mathrm{L}$ to drinking water for 10 days and then $0.4 \mathrm{mg}$ of Helicobacter pylori suspension $5 \times 10^{8} \mathrm{KU} / \mathrm{mL}$ given per os twice daily for 7 days in 3 days. ${ }^{7.8}$ Hyperacidic gastritis was reproduced by the introduction of a single $5 \%$ solution of acetic acid at $4 \mathrm{~mL} / \mathrm{kg}$ of mass through a probe 5 days before the trial. For control intragastric $\mathrm{pH}$-metry was conducted under intraperitoneal anesthesia using sodium thiopental at a dose of $20 \mathrm{mg} / \mathrm{kg}$ of the rat's mass by insertion of a glass electrode (EL-40) into the cavity of the stomach during supramedial laparotomy using a $\mathrm{pH}$ meter $(\mathrm{pH}-340)$. The level of basal acidity in the simulation of hyperacidic gastritis was 1.80-2.00.

In the rats in groups 3 and 4 after the reproduction of hyperacidic gastritis and in group 2 on the first day of the experiment in the first series of experiments under thiopental anesthesia (20 $\mathrm{mg} / \mathrm{kg}$ ) periodontitis was modeled by applying a ligature to the central incisor. The essence of the model consists of the formation of a retention point for the dental plaque, which initiates the development of inflammation and destruction of the periodontal tissues. ${ }^{9}$ In the rats in group 4 in the first series of the experiment and in groups 2, 3, and 4 of the second series 
the conditions for tobacco smoking were created by exposure to the effect of tobacco smoke.

To reproduce the conditions of tobacco smoking, a plastic hermetic chamber of $28 \mathrm{~L}$ with three different sections was used, to which tobacco smoke from 15 cigarettes (primma red with a content of $1.0 \mathrm{mg}$ of nicotine and $10 \mathrm{mg}$ of resin in 1 cigarette) was introduced inside by pressure of the engine, through the holes for $30 \mathrm{~min}$, daily, for 15 days. At the same time, there were 7 animals in the chamber. During cigarette smoking, the behavioral reactions of the rats were observed: initially, the supply of tobacco smoke to the chamber made the rats anxious, looking for a place to breathe normally, and in 10 min they calmed down and fell asleep. After finishing the inhalation of tobacco smoke and supply of fresh air, the rats became active, began to breathe frequently, and 15 min later they returned to normal.

The animals were removed from the experiment in several stages. Euthanasia of rats in groups 1, 2, 3, and 4 of the first series was performed immediately after the last procedure of inhalation of tobacco smoke (on day 15) under thiopental anesthesia $(20 \mathrm{mg} / \mathrm{kg}$ ) by total bloodletting from the heart. All animals treated after reproduced periodontitis against the background of hyperacidic gastritis under tobacco-smoking conditions were slaughtered 8 or 14 days after the beginning of treatment.

A tissue sample of the gum for biochemical studies was taken. In the supernatant fluid of the gum homogenates the final level of the peroxide oxidation of lipid (POL) malondialdehyde (MDA) by the thiobarbituric method was determined ${ }^{10}$ and the antioxidant protection (AOP) status was assessed by activity of catalase ${ }^{11}$ as well as inflammation level by elastase activity ${ }^{12}$ and nonspecific activity protection index lysozyme.13 The antioxidant-prooxidant index of API was calculated by the ratio of catalase activity to MDA concentration.

During the study, the procedures used adhered to the general principles of animal experiments approved at the National Congress on Bioethics (Kyiv, Ukraine, 2001) and were in accordance with the provisions of the European Convention for the Protection of Vertebrate Animals used for experimental and other scientific purposes (Strasbourg, France, 1985). The statistical processing of the data was carried out using the program "Statistica 6.0" using Students t-criterion. The changes were considered to be significant at $p<0.05$.

\section{RESULTS AND DISCUSSION}

The experimental animals had an intact mucous membrane of the gum before the reproduction of pathological conditions, with no apparent pathological changes; gum bleeding was not found on probing. There were manifestations of the clinical symptoms of periodontal tissue inflammation, namely hyperemia, edema, and bleeding of the gum in the area of the incisors in all rats after ligature-induced periodontitis on day 3. On day 5, inflammation was seen in the area of the molars, that is, there was a generalization of the inflammatory process in the periodontal tissues. The animals in which hyperacidic gastritis was reproduced became weak, ate little, and showed inflammatory symptoms of OCM in their oral cavity: hyperemia and edema. After modeling periodontal disease in these animals there was an explicit picture of inflammation in the gums in the form of edema and hyperemia of the marginal region and gingivitis on day 2. There were metabolic changes in the periodontal tissues of the rats, as evidenced by the biochemical parameters of the gum biopsy in the rats in groups 2 and 3 compared to intact animals. The analysis of changes in the biochemical markers of inflammation in the gum tissues of animals determined the most significant deviations in the rats with periodontitis against the background of hyperacidic gastritis under the conditions of intoxication with tobacco smoke (group 4).

Taking into account that one of the main factors that trigger the inflammatory processes is the activation of free radical lipid oxidation, the prooxidant system has been studied for the level of MDA and the activity of AOP in the activity of catalase. Modeling of periodontitis led to an increase in the content of MDA in the gum tissues, which pointed to intensification of POL with decreased activity of AOP (catalase activity decreased) in the periodontal tissues. Even more significant similar changes occurred in the gum biopsy of the animals, in which periodontitis was reproduced against the background of hyperacidic gastritis. The most expressed metabolic disorders in the tissues of the oral cavity were found in group 4 of rats, in which periodontitis was simulated against the background of hyperacidic gastritis under the conditions of smoking, when the combination of the influences of two affecting factors, especially in the system of POL/AOP, was observed. The process of POL activation as the main factor of cell membrane damage due to the action of an excessive stimulus was realized in all tissues, including the mucous membranes of the digestive system. In the tissues of rats, there is a system for counteracting damage and activation of POL; such a counteracting factor is AOP, in particular, the enzyme catalase. The activity of catalase was reduced as a result of its consumption during active participation in the processes of decontamination of the POL products. In group 4, the animals showed the lowest activity of catalase in the gum $(4.96 \pm 0.39$ mcat $/ \mathrm{kg})$ and the highest level of MDA $(19.70 \pm 1.30 \mu \mathrm{mol} / \mathrm{kg})$, which exceeded this index 2.3 times in the intact animals $(p<0.05)$ and 1.3 times in rats in group 2 with periodontitis (Table 1).

Elastic activity, which characterizes the development of inflammation in the gum during reproduction of periodontitis, was most increased under the conditions of combined stomach pathology and the action of tobacco smoke, which indicated high activity of neutrophils that in large numbers infiltrated the periodontal tissues during the development of inflammation.

In the tissues of rats with periodontitis against the background of hyperacidic gastritis, which was influenced by tobacco smoke, elastase activity was 1.35 times higher than that in intact animals ( $p<0.05$ ) without intoxication with tobacco smoke; the studied index increased by $25 \%$ less ( $p<0.05$ ). Concomitant hyperacid gastritis significantly influenced the degree of metabolic disorders of the oral cavity tissues in animals with induced inflammation of the periodontal tissues, enhancing the 
manifestations of oxidative stress, suppressing the functional state of the system of antioxidant protection, and causing damage to biological membranes, and structural and functional changes in the gum mucosa with elements of inflammation. Elastase activity in the gum tissues was increased 1.26 times in rats with periodontitis against the background of hyperacid gastritis compared to intact ones, exceeding values in the rats without combined pathology. At the same time, there was a decrease in the local resistance of the tissues of the oral cavity in groups 3 and 4, which was evidenced by $36.3 \%$ and $44.3 \%$ less lysozyme activity in the gum homogenates compared with intact animals. It is known that lysozyme has a local antiinflammatory and immunomodulating effect: it inhibits the chemotaxis of neutrophils and the production of toxic oxygen radicals. ${ }^{14}$ Reduction in the activity of lysozyme may be the cause of maintaining a local inflammatory process.

The application of a new mucosal apigel Apisan in the local therapy of periodontal disease reconstructed against the background of hyperacidic gastritis under the conditions of intoxication with tobacco smoke contributed to the reduction in the influence of the affecting factors on the animal oral cavity and the restoration of the tissue condition. During the examination of the oral cavity, much less damage to the mucosa was detected, namely swelling and redness of the gums decreased. After local use of the Apisan gel, the condition of the periodontal tissues improved within 5 days of the beginning of treatment, and with application of the comparator (the Asepta gel) in only 10 days. The results of the biochemical studies showed that the newly created drug significantly reduced the markers of inflammation in the gum tissue. Their parameters in the substrate that was studied in the animals in which the new gel was applied to the areas with induced periodontitis had lower values compared with the data of the comparison group. On day 8 after treatment with the new gel, most animals (86\%) were found to have normalization of the antioxidant-prooxidant system, markers of inflammation in the gum tissues.
During the application of the Asepta gel a positive effect was determined in only $38 \%$ of rats on day 8 after the beginning of application, and metabolic disturbances, which were eliminated mainly at the end of the observation, were recorded in the remaining animals (62\%). In the course of a comprehensive study it was found that the Apisan gel gave a more pronounced therapeutic effect than the Asepta gel, characterized by an improvement in the biochemical indices of the rat periodontal tissues (Table 2).

Thus, summing up the results of experimental studies, it is possible to state that rats during the reproduction of periodontitis against the background of hyperacidic gastritis under the conditions of intoxication with tobacco smoke had increased activity of the prooxidant system and decreased activity of the antioxidant system, and elastase activity increased in decreasing nonspecific protection in the periodontal tissues, indicating the development of the inflammatory process. The application of the newly created Apisan apigel for application in periodontal disease in rats against the background of hyperacidic gastritis after intoxication with tobacco smoke significantly reduced the processes of inflammation in the periodontal tissues, affecting the normalization of the POL processes, inflammation, and activation of the protective systems of the oral cavity.

\section{CONCLUSION}

1. In experimental periodontitis against the background of hyperacidic gastritis under the conditions of intoxication with tobacco smoke, changes in the periodontal tissue are characteristic of the inflammatory process: the activity of lipid peroxidation increases and the activity of the antioxidant system decreases, and the markers of inflammation increase in decreasing nonspecific protection.

2. Local therapy of periodontal disease reconstructed against the background of hyperacidic gastritis with the effect of tobacco smoke in rats using the newly created apigel Apisan

Table 1. Changes in biochemical parameters in the gum tissues in the rats in which periodontitis was reproduced against the background of hyperacid gastritis

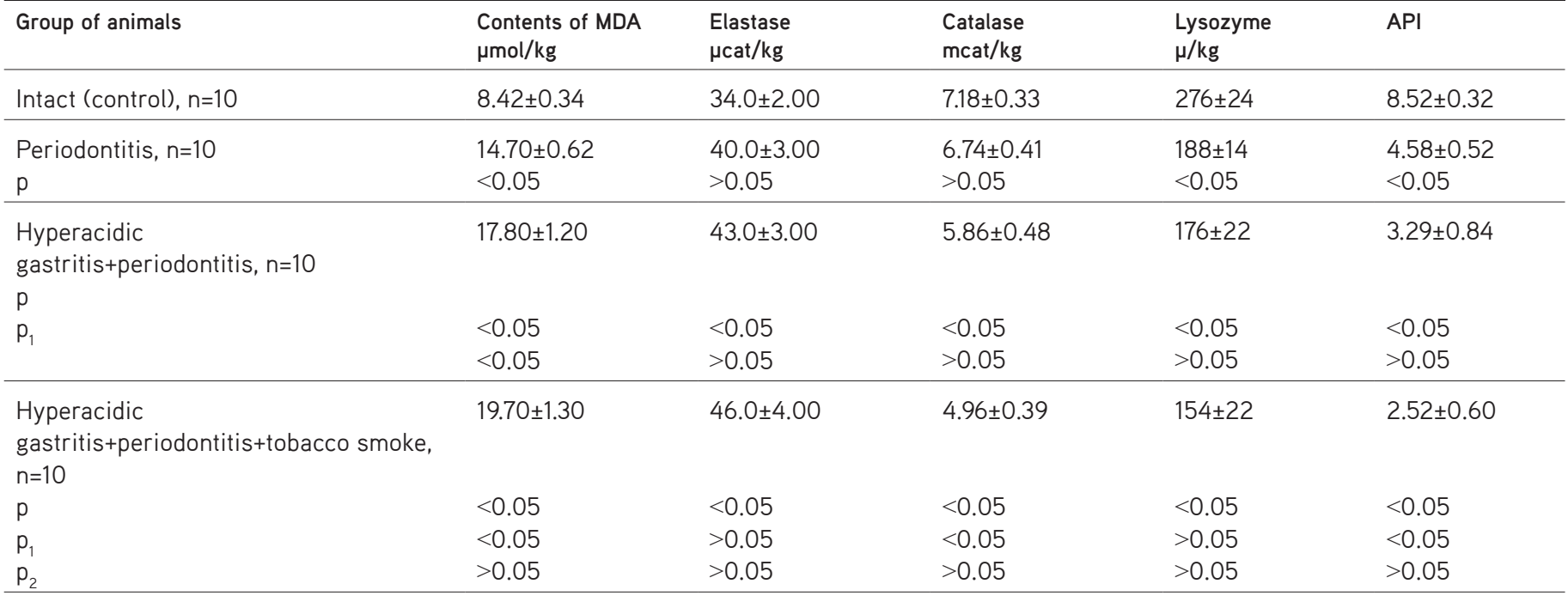

p: Probability relative to the control group, $p_{1}$ : Probability of the periodontitis group, $p_{2}$ : Probability of differences between groups 3 and 4 , MDA: Malondialdehyde 
Table 2. Correction of metabolic disorders in the periodontal tissues of rats in the local treatment of reconstructed periodontitis against the background of hyperacidic gastritis $(M \pm t)$

\begin{tabular}{|c|c|c|c|c|c|}
\hline Group of animals & $\begin{array}{l}\text { Contents of } \\
\mathrm{MDA} \\
\mu \mathrm{mol} / \mathrm{kg}\end{array}$ & $\begin{array}{l}\text { Elastase } \\
\mu \mathrm{cat} / \mathrm{kg}\end{array}$ & $\begin{array}{l}\text { Catalase } \\
\mathrm{mcat} / \mathrm{kg}\end{array}$ & $\begin{array}{l}\text { Activity } \\
\text { Lysozyme } \\
\mu / \mathrm{kg}\end{array}$ & API \\
\hline Intact (control) $n=10$ & $8.42 \pm 0.34$ & $34.0 \pm 2.0$ & $7.18 \pm 0.33$ & $276 \pm 24$ & $8.52 \pm 0.32$ \\
\hline $\begin{array}{l}\text { Hyperacidic } \\
\text { gastritis+periodontitis+tobacco smoke, } n=10\end{array}$ & $19.7 \pm 1.30$ & $46.0 \pm 4.0$ & $4.96 \pm 0.39$ & $154 \pm 34$ & $2.52 \pm 0.80$ \\
\hline $\mathrm{p}$ & $<0.05$ & $<0.05$ & $<0.05$ & $<0.05$ & $<0.05$ \\
\hline $\begin{array}{l}\text { Comparison group, } n=10 \\
p \\
p_{1} \\
p_{2}\end{array}$ & $\begin{array}{l}13.31 \pm 0.74 \\
<0.05 \\
<0.05 \\
<0.05\end{array}$ & $\begin{array}{l}40.0 \pm 3.0 \\
>0.05 \\
>0.05 \\
>0.05\end{array}$ & $\begin{array}{l}6.23 \pm 0.42 \\
<0.05 \\
<0.05 \\
>0.05\end{array}$ & $\begin{array}{l}197 \pm 22 \\
<0.05 \\
>0.05 \\
>0.05\end{array}$ & $\begin{array}{l}4.68 \pm 0.58 \\
<0.05 \\
<0.05 \\
<0.05\end{array}$ \\
\hline
\end{tabular}

$\mathrm{p}$ : Probability relative to the control group, $\mathrm{p}_{1}$ : Probability relative to the data before treatment, $\mathrm{p}_{2}$ : probability of differences between the main group and the comparison group MDA: Malondial dehyde

led to the correction of certain metabolic disorders in the gum homogenate, and faster elimination of the harmful effects of the damaging factors and restoration of the state of the periodontal tissues than in comparative application of Asepta gel.

3. The therapeutic efficacy of the Apisan gel is due to a normalizing effect on the processes of POL, inflammation, and activation of the oral protective systems.

4. The results of the studies give grounds for recommending the local application of the new Apisan apigel to prevent inflammatory processes in the tissues of the oral cavity against the background of concomitant hyperacidic gastritis and to create optimal conditions for the elimination of structural and functional disorders caused by endogenous and exogenous risk factors such as tobacco smoke. ${ }^{15}$

\section{PROSPECTS FOR FURTHER RESEARCH}

The results obtained in the experiment indicate the expediency of studying the effect of the developed treatment on indices of nonspecific resistance and immune reactivity in the oral cavity during periodontitis against the background of concomitant GIT pathology and the creation of recommendations for its application in the complex therapy of dental diseases.

Conflicts of interest: No conflict of interest was declared by the authors.

\section{REFERENCES}

1. Yarova S. Features of the distribution and course of inflammatory and dystrophic processes in the periodontium against the background of diseases of the gastrointestinal tract. Ukr Dent Almanac. 2014;2:105-107.

2. Orekhova LYu. Clinical features and tendencies in the periodontal status of smokers. Parodontology. 2011;1:47-50.

3. Gazhva S. An integrated approach to the treatment of the oral mucous membranes in patients with chronic gastritis. Dentistry. 2013;6:16-19.

4. Beloklitskaya $\mathrm{G}$. Dental manifestations in the oral cavity in patients with diseases of the gastrointestinal tract. Ukr Dent Almanac. 2010;2:66-68.
5. Oshakbayev K, Abilayuly Zh, Amanov T, Kozhazbekova B. Factors associated with tobacco smoking. Prevention of Diseases and Strengthening of Health. 2007;2:22-26.

6. Kravchenko L. A patent for the useful model of Ukraine №119715 IPC (2015.01) A61K31 / 235 Apisan gel for local treatment and prevention of traumatic lesions of the oral mucosa. Applicant and patent holder of Odessa National Medical University, №201702028 of 10, 03.2017, 2017; 21. Available from: http://uapatents.com/6-119715-gel-apisan-dlya-miscevo-profilaktiki-talikuvannya-travmatichnikh-urazhen-slizovo-obolonki-porozhnini-rota.html

7. Khomenko L, Savichuk O, Kostiuk O. A patent of Ukraine for invention 38149 A7A61B13 / 00 A61B10 / 00 Method of modeling of chronic relapsing aphthous stomatitis. Applicant and Patent holder of National Medical University named after 0.0. Bogomolets, №2000063173 of 02.06.2000; published on May 15, 2001; 4. Available from: http:// uapatents.com/3-38149-sposib-modelyuvannya-khronichnogorecidivuyuchogo-aftoznogo-stomatita.html

8. Li H, Mellgard B, Helander H. Inoculation of VacA- and CagA-Helicobacter pylori delays gastric ulcers healing in the rat. Scand J Gastroenterol. 1997;32:439-444.

9. Struillou $X$, Boutigny $H$, Soueidan A, Layrolle P. Experimental animal models in periodontology: a review. Open Dent J. 2010;4:37-47.

10. Stalnaya I, Garishvili T. A method for the determination of malonic diaaldehyde with tiobarbituric acid. Modern Methods in Biochemistry. 1977:66-68.

11. Koroliuk MA, Ivanova LI, Maĭorova IG, Tokarev VE. A method of determining catalase activity. Lab Delo. 1988;1:16-19.

12. Levitsky A, Denga O, Makarenko O. Biochemical markers of inflammation of the tissues of the oral cavity: study guide. Odessa. 2010:16.

13. Kulakov E, Zorina O, Boriskinf A. The role of protective factors of the organism in the pathogenesis of inflammatory periodontal diseases. Dentistry. 2010;6:72-76.

14. Apatzidou D, Riggio MP, Kinane DF. Impact of smoking on the clinical, microbiological and immunological parameters of adult patients with periodontitis. J Clin Periodontol. 2005;32:973-983.

15. Batsaeva YuG, Begimbetova K, Fedorov D, Yakushenko V, Zharmaev S. Clinical and laboratory study of preparations based on propolis in the treatment of periodontal and oral mucosa. Saratov Scientific Medical Journal. 2018;2:133-136. 